\title{
Ozone weekend effects in the Beijing-Tianjin-Hebei metropolitan area, China
}

\author{
Y. H. Wang ${ }^{1,2}$, B. Hu ${ }^{1}$, D. S. Ji ${ }^{1}$, Z. R. Liu ${ }^{1}$, G. Q. Tang ${ }^{1}$, J. Y. Xin ${ }^{1}$, H. X. Zhang ${ }^{3}$, T. Song ${ }^{1}$, L. L. Wang ${ }^{1}$, W. K. Gao ${ }^{1}$, \\ X. K. Wang ${ }^{3}$, and Y. S. Wang ${ }^{1}$ \\ ${ }^{1}$ State Key Laboratory of Atmospheric Boundary Layer Physics and Atmospheric Chemistry (LAPC), Institute of \\ Atmospheric Physics, Chinese Academy of Sciences, Beijing, 100029, China \\ ${ }^{2}$ College of Atmospheric Science, Lanzhou University, Lanzhou, 730000, China \\ ${ }^{3}$ Research Center for Eco-Environmental Sciences, Chinese Academy of Sciences, Beijing, 100085, China
}

Correspondence to: Y. S. Wang (wys@dq.cern.ac.cn) and B. Hu (hb@dq.cern.ac.cn)

Received: 10 April 2013 - Published in Atmos. Chem. Phys. Discuss.: 17 May 2013

Revised: 19 January 2014 - Accepted: 23 January 2014 - Published: 10 March 2014

\begin{abstract}
The ozone weekend effect (OWE) was first investigated in the metropolitan area of Beijing-Tianjin-Hebei (BTH), China, using in situ measurements from the Atmospheric Environment Monitoring Network from July 2009 to August 2011. The results indicate that there is an obvious weekly periodical variation in the surface ozone concentration. There is a lower ozone concentration from Wednesday to Friday (weekday) and a higher concentration from Saturday to Monday (weekend) at all the locations of the study. $\mathrm{NO}_{\mathrm{x}}$ also displays a weekly cycle, with the maximum level occurring on weekdays and the minimum level on weekends, especially later on Sunday night and early Monday morning. This pattern may be responsible for the higher concentration of ozone on weekends. Additionally, the vertical variations in $\mathrm{O}_{3}$ and $\mathrm{NO}_{\mathrm{x}}$ from the $8 \mathrm{~m}, 47 \mathrm{~m}, 120 \mathrm{~m}$ and $280 \mathrm{~m}$ observation platforms on the $325 \mathrm{~m}$ Beijing meteorological tower displayed obvious weekly cycles that corresponded to the surface results.

A smaller decrease in volatile organic compounds (VOCs; using $\mathrm{CO}$ as a proxy) and much lower $\mathrm{NO}_{\mathrm{x}}$ concentrations on the weekend may lead to higher $\mathrm{VOC} / \mathrm{NO}_{\mathrm{x}}$ ratio, which can enhance the ozone production efficiency in VOC-limited regime areas. Additionally, a clear weekly cycle in the fine aerosol concentration was observed, with maximum values occurring on weekdays and minimum values occurring on weekends. Higher concentrations of aerosol on weekdays can reduce the UV radiation flux by scattering or absorbing, which leads to a decrease in the ozone production efficiency. A significant weekly cycle in UV radiation, consistent with
\end{abstract}

the aerosol concentration, was discovered at the Beijing meteorological tower site (BJT), validating the assumption. A comprehensive understanding of the ozone weekend effect in the BTH area can provide deep insights into controlling photochemical pollution.

\section{Introduction}

Surface ozone $\left(\mathrm{O}_{3}\right)$, as a main secondary air pollutant, has caused great concern due to its adverse effects on human health and vegetation (NRC, 1991). $\mathrm{O}_{3}$ is predominantly produced through the photochemical oxidation of non-methane volatile organic compounds (NMVOCs) and carbon monoxide (CO) in the presence of nitrogen oxides (Fishman and Crutzen, 1978; Seinfeld and Pandis, 1998). Additionally, stratospheric ozone can also be transported into the troposphere and contribute to the concentration of surface ozone. The ozone weekend effect (OWE) is a phenomenon that was first reported in the 1970s (Cleveland et al., 1974; Lebron, 1975; Levitt and Chock, 1976; Karl, 1978). In this phenomenon, the surface ozone concentration in urban areas tends to be higher on weekends than on weekdays despite the lower concentration of ozone precursors $\left(\mathrm{NO}_{\mathrm{x}}\right.$ and volatile organic compounds (VOCs)). Currently, the mechanisms that drive the OWE are still not well understood. The surface ozone concentration is controlled by a series of complex physical and chemical processes in relation to precursor emissions, local meteorological conditions and 


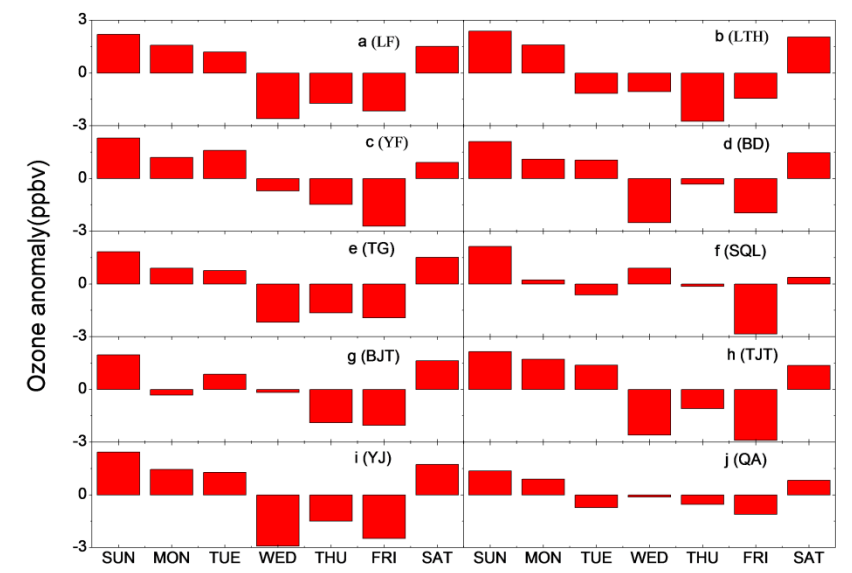

Fig. 1. Weekly variation of surface ozone concentration anomalies at these sites.

photochemical reactions, along with the city's economic structure and local pollutant emissions. The California Air Resources Board (2003) has proposed several hypotheses to explain the OWE. An appropriate understanding of the OWE may provide insights into the effectiveness of control strategies for ozone pollution, because these plans typically focus on reducing the emission of ozone precursors. A robust understanding of the OWE can also validate the performance of models by simulating ozone concentrations under different emission scenarios (Koo et al., 2012). The OWE has been extensively studied in the US and Europe using in situ measurements, numerical simulations and satellite retrieval (Cleveland and McRae, 1978; Altshuler et al., 1995; Beirle et al., 2003; Fujita et al., 2003; Atkinson-Palombo et al., 2006; Murphy et al., 2007; Koo et al., 2012). However, the study of the OWE in Asia is limited due to the small number of observation sites compared to America and Europe. Only few investigations have been conducted in Shanghai (Tang et al., 2008), the Kathmandu Valley (Pudasainee et al., 2010), Taiwan and Japan (Tasi, 2005; Sadanaga et al., 2008).

The metropolitan area of BHT is located in the centre of northeast Asia, including two megalopolises (Beijing and Tianjin) and several prosperous cities (Baoding, Tanggu, Langfang, etc.). Accompanying the rapid growth in traffic and the economy, the photochemical pollution has caused great concern over the last few decades (Wang et al., 2006, 2011; Chan et al., 2008; Chou et al., 2009; J. Xu et al., 2011; W. Y. Xu et al., 2011; Lin et al., 2011). For example, the ambient air quality standard for ozone has frequently been exceeded, and an hourly averaged concentration of $286 \mathrm{ppb}$ has been recorded (Wang et al., 2006). $\mathrm{NO}_{2}$ increased by $5.7 \%$ during the first half of 2011, compared to the same period in 2010 (MEP, 2011), in many key cities for environmental protection in China. In particular, China's new "Twelfth Five-Year Plan" has set a target for total $\mathrm{NO}_{\mathrm{x}}$ emissions reductions of 10\% for 2011-2015 (China State Council, 2011; Wu et al., 2012). Studying the OWE can provide us deep in-

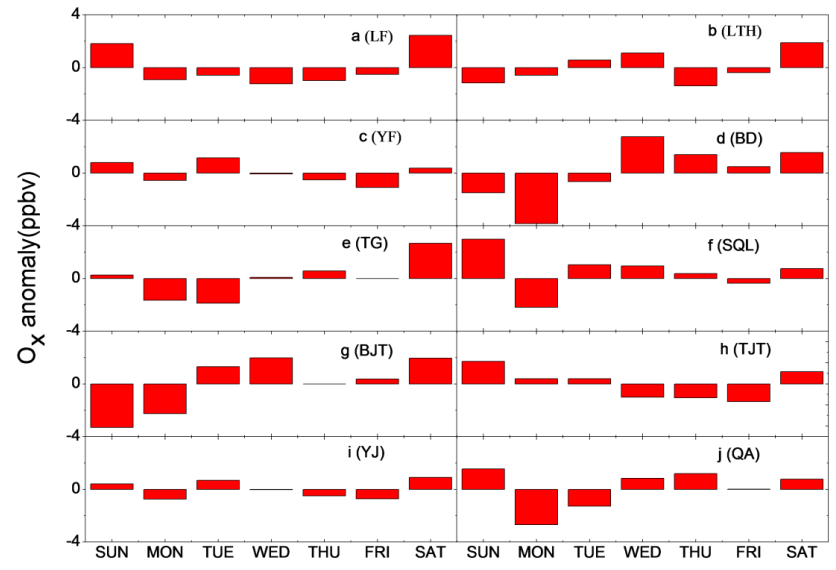

Fig. 2. Weekly variations of $\mathrm{O}_{\mathrm{x}}$ concentration anomalies at these sites.

sight into the influence of a decrease in $\mathrm{NO}_{\mathrm{x}}$ on surface ozone over a large scale.

We investigated horizontal and vertical weekly variation ozone concentration in the Beijing-Tianjin-Hebei (BTH) region using real-time, online data from the Atmospheric Environment Monitoring Network. Furthermore, simultaneous measurements of $\mathrm{NO}, \mathrm{NO}_{\mathrm{x}}, \mathrm{CO}, \mathrm{PM}_{10}$ (particles with aerodynamic equivalent diameters of less than $10 \mu \mathrm{m}$ ) and $\mathrm{PM}_{2.5}$ (particles with aerodynamic equivalent diameters of less than $2.5 \mu \mathrm{m}$ ) were also recorded to study the causes of the OWE, in addition to relevant data for ultraviolet radiation that were collected at the Beijing meteorological tower site (BJT).

\section{Methodology}

\subsection{A description of the Atmospheric Environment Monitoring Network}

Ten sites from the Atmospheric Environment Monitoring Network were used. The network had an extensive coverage over the $\mathrm{BTH}$ area and provided a comprehensive data set for air pollutants $\left(\mathrm{PM}_{10}, \mathrm{PM}_{2.5}, \mathrm{O}_{3}, \mathrm{NO}, \mathrm{NO}_{2}, \mathrm{NO}_{\mathrm{x}}, \mathrm{SO}_{2}\right.$ and CO) in real time (Tang et al., 2012; Ji et al., 2012). Urban and suburban areas are significantly influenced by local emissions from motor vehicles, coal-fired power plants, and industrial facilities. Therefore, these observation sites, located in urban and suburban areas in the BTH region, were selected for the study of weekly ozone variation. As depicted in Fig. 2, there were four sites in Beijing: the $325 \mathrm{~m}$ meteorological tower (BJT), Longtanhu (LTH), Shuangqinglu (SQL) and Yangfang (YF). In addition, there were two sites in Tianjin: the $255 \mathrm{~m}$ tower of Tianjin (TJT) and Tanggu (TG). There were also four urban and suburban sites surrounding Beijing and Tianjin: Baoding (BD), Yanjiao (YJ), Langfang (LF) and Qian'an (QA). Table 1 lists general information about the sites. The sites were far away from specific point emission 

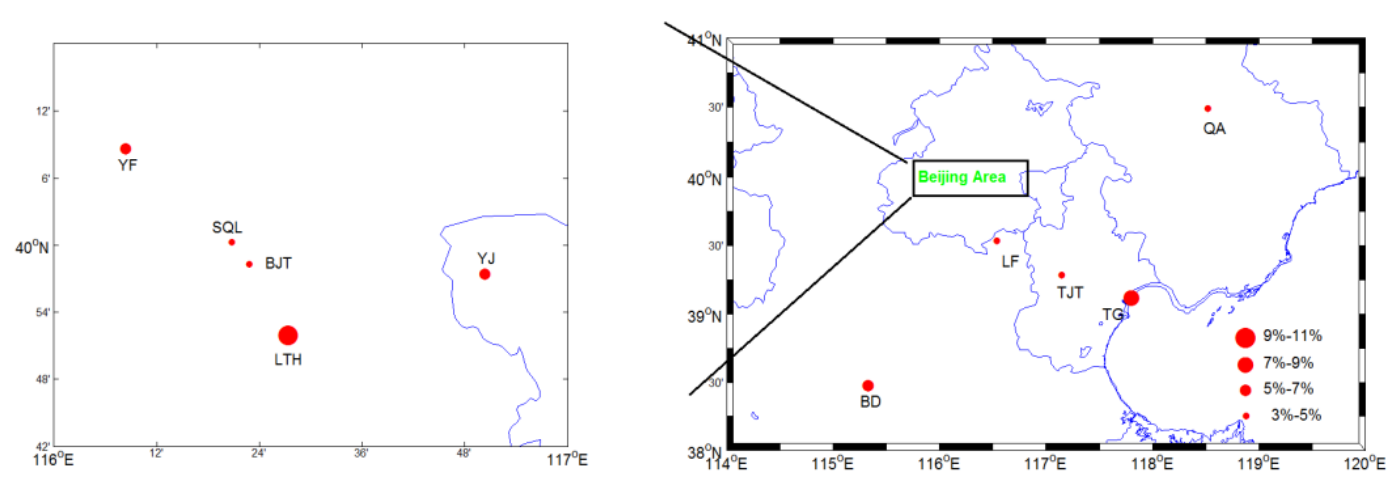

Fig. 3. The magnitude of OWE (percentage) and site locations over the BTH area, and detailed site positions in the Beijing area are presented in the left figure. The size of the point stands for the magnitude of OWE at each site, and the blue line stands for provincial boundary.

sources and were broadly representative of photochemical pollution.

\subsection{Instruments and methods}

The selected sites were set up according to the US EPA methodological designations (US EPA, 2004), and the measurement instruments were housed in a laboratory that was equipped with an air conditioner. Ozone was measured with a Model 49i or 49c ozone analyser from Thermo Environmental Instruments (TEI) Inc. The ozone analyser had a detection limit of $1 \mathrm{ppbv}$ and a precision of $1 \mathrm{ppbv}$. CO concentrations were documented using TEI Model $48 \mathrm{i}$ instruments, with a detection limit of 0.04 ppmv and a precision of 0.1 ppmv. $\mathrm{NO}_{\mathrm{x}}$ and $\mathrm{NO}$ concentrations were measured using the TEI Model 42c and 42 CTL analysers. Both of the $\mathrm{NO}_{\mathrm{x}}$ analysers had a precision of $0.4 \mathrm{ppbv}$, and the detection limits for Models $42 \mathrm{c}$ and 42 CTL were $0.4 \mathrm{ppbv}$ and $0.05 \mathrm{ppbv}$, respectively. Ambient air samples for both the $\mathrm{NO}-\mathrm{NO}_{\mathrm{x}}$ and $\mathrm{O}_{3}$ analyser were drawn through a $3 \mathrm{~m}$ PFA Teflon tube (outside diameter: $12.7 \mathrm{~mm}$; inside diameter: $9.6 \mathrm{~mm}$ ), and the sampling tube inlets were located $1 \mathrm{~m}$ above the laboratory. Multipoint calibrations of the $\mathrm{O}_{3}$ analyser were conducted using a zero air supplier (Model 111) and a calibrator (TE 49c PS). The calibration of the NO$\mathrm{NO}_{\mathrm{x}}$ analyser was conducted with a dynamic gas calibrator (Model 146) in conjunction with a zero air supplier (Model 111). Additional detailed calibration work is described in Tang et al. (2012). The concentrations of particles $\left(\mathrm{PM}_{10}\right.$ and $\left.\mathrm{PM}_{2.5}\right)$ were measured using a TEOM RP1400 (Thermo Scientific, http://www.thermoscientific.com) with $0.1 \mu \mathrm{g} \mathrm{m}^{-3}$ resolution, $\pm 1.5 \mu \mathrm{g} \mathrm{m}^{-3} 1 \mathrm{~h}$ average precision, $\pm 0.5 \mu \mathrm{g} \mathrm{m}^{-3} 24 \mathrm{~h}$ average precision, and a detection limit of $0.06 \mu \mathrm{g} \mathrm{m}^{-3}$ ( $1 \mathrm{~h}$ average). The filters were exchanged when the loading rates were approximately $40 \%$, and the flow rates were monitored and calibrated monthly. Highresolution (5 min averages) data sets of $\mathrm{O}_{3}, \mathrm{NO}, \mathrm{NO}_{\mathrm{x}}, \mathrm{CO}$, $\mathrm{PM}_{10}$ and $\mathrm{PM}_{2.5}$ from July 2009 to August 2011 were obtained, and hourly averaged data were used after applying strict data quality control; no data were available on some days due to instrument malfunction and power failure. In particular, the data obtained on holidays, such as the Spring Festival, National Day and May Day, were removed from our study due to false representation of weekly human activities. Simultaneous measurements of UV radiation were also used to validate the weekly cycle of UV radiation, which is needed for ozone formation. The UV radiation $(290-400 \mathrm{~nm})$ was measured at the Beijing Tower using CUV3 (Kipp \& Zonen, the Netherlands) with an accuracy of $5 \%$. The radiation data were recorded at $1 \mathrm{~min}$ intervals, and the daily average values that were used in the study were derived from hourly values that were averaged from minute values. The calibration of the sensor and the quality control for the sample data were described in detail by Hu et al. (2008).

The weekend effect has been defined in many ways. We chose to define the weekend effect as percentage of (weekend - weekday)/weekday. The difference $(W)$ is the average ozone concentration of Wednesday, Thursday and Friday minus the average concentration of Saturday, Sunday and Monday. The same definition of weekend and weekday was also used for the weekly analysis (Forster et al., 2003; Gong et al., 2006; Xia et al., 2008; Ho et al., 2009).

\section{Results and discussion}

\subsection{The weekly cycle of surface ozone concentration}

The daytime (08:00-18:00 averaged) statistical results for the average $\mathrm{O}_{3}, \mathrm{NO}$ and $\mathrm{NO}_{\mathrm{x}}$ concentrations and their per cent differences on weekdays and weekends at 10 sites are summarized in Table 2. On average, the concentration of the secondary pollutant ozone is significantly low while concentration of the primary pollutant $\mathrm{NO}_{\mathrm{x}}$ is high in these urban areas. This effect is attributed to the fact that the urban areas have a $\mathrm{NO}_{\mathrm{x}}$-saturated regime (Wang et al., 2010; Tang et al., 2012). The ozone level ranged from $22.65 \mathrm{ppb}(\mathrm{QA})$ to $35.65 \mathrm{ppb}$ $(\mathrm{LF})$, whereas $\mathrm{NO}_{\mathrm{x}}$ remained at a high concentration. The 
Table 1. General information about the sites and parameters used in the study.

\begin{tabular}{llrrrl}
\hline Site & Site type & Longitude & Latitude & Altitude & Parameter \\
\hline Langfang (LF) & Suburban & 116.69 & 39.55 & 19 & $\mathrm{O}_{3}, \mathrm{NO} \mathrm{NO}_{\mathrm{x}}$ and $\mathrm{PM}_{10}$ \\
Longtanhu (LTH) & Urban & 116.43 & 39.87 & 40 & $\mathrm{O}_{3}, \mathrm{NO}_{\mathrm{x}} \mathrm{NO}_{\mathrm{x}}$ and $\mathrm{PM}_{2.5}$ \\
Yangfang (YF) & Suburban & 116.13 & 40.15 & 40 & $\mathrm{O}_{3}, \mathrm{NO}, \mathrm{NO}_{\mathrm{x}}$ and $\mathrm{PM}_{10}$ \\
Baoding (BD) & Urban & 115.44 & 38.82 & 4 & $\mathrm{O}_{3}, \mathrm{NO}, \mathrm{NO}_{\mathrm{x}}$ and $\mathrm{PM}_{10}$ \\
Tanggu (TG) & Urban & 117.72 & 39.04 & 13 & $\mathrm{O}_{3}, \mathrm{NO}, \mathrm{NO}_{\mathrm{x}}$ and $\mathrm{PM}_{2.5}$ \\
Shuangqinglu (SQL) & Urban & 116.34 & 40.01 & 58 & $\mathrm{O}_{3}, \mathrm{NO}, \mathrm{NO}_{\mathrm{x}}$ and $\mathrm{PM}_{2.5}$ \\
Beijing Tower (BJT) & Urban & 116.37 & 39.97 & 44 & $\mathrm{O}_{3}, \mathrm{NO}, \mathrm{NO}_{\mathrm{x}}, \mathrm{CO}_{2 .} \mathrm{PM}_{2.5}, \mathrm{PM}_{10}$ and $\mathrm{UV}$ \\
Tianjin Tower (TJT) & Urban & 117.21 & 39.08 & 2 & $\mathrm{O}_{3}, \mathrm{NO}, \mathrm{NO}_{\mathrm{x}}, \mathrm{CO}, \mathrm{PM}_{10}$ and $\mathrm{PM}_{2.5}$ \\
Yangjiao (YJ) & Suburban & 116.82 & 39.96 & 26 & $\mathrm{O}_{3}, \mathrm{NO}, \mathrm{NO}_{\mathrm{x}}$ and $\mathrm{PM}_{10}$ \\
Qian'an (QA) & Urban & 118.80 & 40.10 & 38 & $\mathrm{O}_{3}, \mathrm{NO}, \mathrm{NO}_{\mathrm{x}}$ and $\mathrm{PM}_{10}$ \\
\hline
\end{tabular}

Table 2. Weekday and weekend differences in $\mathrm{O}_{3}$, $\mathrm{NO}$ and $\mathrm{NO}_{\mathrm{x}}$ using daytime data (08:00-18:00) at these sites.

\begin{tabular}{|c|c|c|c|c|c|c|c|c|c|c|c|c|}
\hline & \multicolumn{3}{|c|}{$\begin{array}{c}\text { Weekday } \\
\text { (ppbv) }\end{array}$} & \multicolumn{3}{|c|}{$\begin{array}{l}\text { Weekend } \\
\text { (ppbv) }\end{array}$} & \multicolumn{3}{|c|}{$\begin{array}{c}\Delta W \\
(\mathrm{ppbv})\end{array}$} & \multicolumn{3}{|c|}{$\begin{array}{c}\text { Percentage } \\
(\%)\end{array}$} \\
\hline & $\mathrm{O}_{3}$ & NO & $\mathrm{NO}_{\mathrm{x}}$ & $\mathrm{O}_{3}$ & NO & $\mathrm{NO}_{\mathrm{x}}$ & $\mathrm{O}_{3}$ & NO & $\mathrm{NO}_{\mathrm{x}}$ & $\mathrm{O}_{3}$ & NO & $\mathrm{NO}_{\mathrm{x}}$ \\
\hline $\mathrm{LF}$ & 34.9 & 14.3 & 38.0 & 36.4 & 13.9 & 37.1 & 1.5 & 0.4 & 0.9 & 4.3 & 2.8 & 2.4 \\
\hline LTH & 28.4 & 17.6 & 44.6 & 31.1 & 13.8 & 38.3 & 2.7 & 3.8 & 6.3 & 9.5 & 21.6 & 14.1 \\
\hline YF & 31.3 & 7.3 & 26.4 & 33.4 & 4.8 & 21.3 & 1.1 & 2.5 & 5.1 & 6.7 & 34.2 & 19.3 \\
\hline $\mathrm{BD}$ & 31.1 & 21.3 & 56.4 & 32.8 & 16.9 & 47.8 & 1.7 & 3.4 & 8.6 & 5.5 & 16 & 15.2 \\
\hline TG & 25.2 & 16.8 & 47.2 & 27.4 & 14.9 & 43.1 & 2.2 & 1.9 & 4.9 & 8.7 & 11.3 & 10.4 \\
\hline SQL & 32.2 & 26.5 & 51.2 & 33.4 & 17.9 & 39.8 & 1.2 & 8.6 & 11.3 & 3.7 & 32.4 & 22.1 \\
\hline BJT & 25.4 & 17.8 & 47.7 & 26.4 & 13.9 & 40.3 & 1 & 3.9 & 7.4 & 3.9 & 21.9 & 15.5 \\
\hline TJT & 26.4 & 20.3 & 45.5 & 27.3 & 18.4 & 43.4 & 0.9 & 1.9 & 2.1 & 3.4 & 9.4 & 4.6 \\
\hline YJ & 30.5 & 12.8 & 27.4 & 32.1 & 11.2 & 23.5 & 1.6 & 1.6 & 3.9 & 5.2 & 12.5 & 14.2 \\
\hline QA & 22.2 & 14.9 & 31.4 & 23.1 & 13.5 & 30.7 & 0.9 & 1.4 & 0.7 & 4.1 & 9.4 & 2.2 \\
\hline
\end{tabular}

average minimum ozone level occurred at QA, BJT and TG, but the average maximum ozone level occurred at LF, SQL and BD. The surface ozone concentrations were higher on weekends than weekdays, as illustrated in Fig. 1. The higher ozone concentrations all occurred on Sunday, but the lower ozone concentrations occurred on Wednesday, Thursday and Friday. The Sunday ozone effect in the BTH area is the same as those studies from Phoenix (Atkinson-Palombo et al., 2006), California (Fujita et al., 2003), Sacramento (Murphy et al., 2007), Mexico City (Stephens et al., 2008), France (Pont et al., 2001), Japan (Sadanaga et al., 2008), Nepal (Pudasainee et al., 2010) and Shanghai (Tang et al., 2009), which all had maximum ozone levels on Sunday. The detailed interpretations will be discussed in the next section. We also investigated the OWE, as detailed in Table 2. The OWE (percentage) was calculated using the following equation:

ozoneweekendeffect $(\mathrm{OWE})=$

([weekend] - [weekday])/[weekday]

The results in Table 2 indicate that OWE varies from $3.4 \%$ at TJT to $8.7 \%$ at TG and $9.5 \%$ at LTH, which suggests that significant weekly human activity may influence weekly variation in ozone concentrations at this highly industrialized area of TG. However, inland sites, such as LF, YF, BD,
SQL, TJT and BJT, are always subject to a large amount of ozone precursor emissions from their daily life, such as vehicle emissions and cooking emissions, which may not vary as significantly as factory emissions on every day of week. Consequently, these sites have a moderate weekend effect compared with TG.

We also investigated the weekend effect for $\mathrm{O}_{x}$ $\left(\mathrm{O}_{\mathrm{x}}=\mathrm{O}_{\mathrm{x}}+\mathrm{NO}_{2}\right)$ as depicted in Fig. 2. The result showed that some sites (LF, LTH, BJT, TJT, YJ and QA) have positive $\mathrm{O}_{\mathrm{x}}$ weekend effect, while the other sites (YF, BD, TG and SQL) have negative $\mathrm{O}_{\mathrm{x}}$ weekend effect. As shown in Fig. 2, the weekly variations of $\mathrm{O}_{\mathrm{x}}$ are different from site to site. There were no consistent maximum or minimum values that occurred on a fixed day. For example, the maximum $\mathrm{O}_{\mathrm{x}}$ concentration at LF site occurred on Saturday, while that at $\mathrm{BD}$ site occurred on Wednesday. We think a high level of $\mathrm{NO}_{2}$ pollution at these sites should be responsible for these negative $\mathrm{O}_{\mathrm{x}}$ weekend effects. The $\mathrm{O}_{\mathrm{x}}$ weekend effect was mainly due to termination reaction $\left(\mathrm{NO}_{2}+\mathrm{OH} \rightarrow \mathrm{HNO}_{3}\right)$, while $\mathrm{O}_{3}$ weekend effect was due to a both termination and titration ( $\mathrm{NO}+\mathrm{O}_{3} \rightarrow \mathrm{NO}_{2}+\mathrm{O}_{2}$ ). We also evaluated the relative importance of these two reactions by comparing the difference of $\mathrm{O}_{x}$ weekend effect and the $\mathrm{O}_{3}$ weekend effect as shown in Table 3. A positive difference indicated that the 


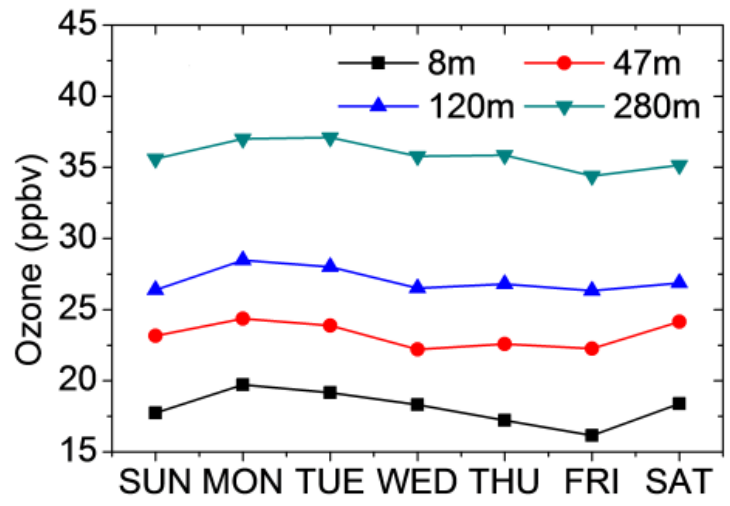

Fig. 4. Weekly variation in ozone concentrations on $8 \mathrm{~m}, 47 \mathrm{~m}$, $120 \mathrm{~m}$ and $280 \mathrm{~m}$ platforms of the Beijing meteorological tower.

termination reaction may be more important at BJT and TJT sites, while a negative difference indicated that titration may be more powerful at rest of the sites.

The vertical ozone concentrations derived from the $8 \mathrm{~m}$, $47 \mathrm{~m}, 120 \mathrm{~m}$ and $280 \mathrm{~m}$ platforms of $325 \mathrm{~m}$ Beijing meteorological tower are depicted in Fig. 4. There were higher ozone concentrations on the first days of week and lower concentrations on the later days of week. The maximum ozone value occurred on Monday, while the minimum value occurred on Friday at all observation platforms using $24 \mathrm{~h}$ averaged values. However, the ozone concentration at the high platform had minimal variability, but at the low platform ozone was significantly variable. The OWEs at $8 \mathrm{~m}, 47 \mathrm{~m}, 120 \mathrm{~m}$ and $280 \mathrm{~m}$ are $8.1 \%, 7.1 \%, 2.7 \%$ and $1.6 \%$, respectively.

The surface ozone concentration observed at a monitoring site is an integrated quantity that is determined by the timing and strength of upwind precursor emissions and the rates of photochemistry and transport. Ozone formation is initiated by $\mathrm{OH}$ radicals, whose concentration profile roughly follows solar radiation and attains maximum level near midday. To extend our understanding of the OWE at an individual site, we describe the daily behaviour of surface ozone concentrations, as illustrated in Fig. 5(a-j). Typical patterns of variation for middle latitude urban cities were observed, and the maximum concentrations were observed at approximately 15:00 LT (local time). The surface ozone attained its minimum concentration early in the morning (02:00-06:00), as illustrated in Fig. 5a-j, mainly due to a closure of photochemical reactions (Seinfeld and Pandis, 1998). The peak values at the 10 sites occurred on Sunday or Monday. Sites such as LF (Fig. 5a), LTH (Fig. 5b), YF (Fig. 5c), SQL (Fig. 5f), TJT (Fig. 5h) and YJ (Fig. 5j) had higher concentrations on weekends than early on weekday mornings, especially on Monday and Tuesday, which may be related to a decrease in vehicle emissions on weekend nights. The ozone concentrations at the site BD (Fig. 5d) and the SQL (Fig. 5f) peak earlier than other days. This may be due to lower $\mathrm{NO}_{\mathrm{x}}$ emission at Sunday night and early Monday morning, which leads to high
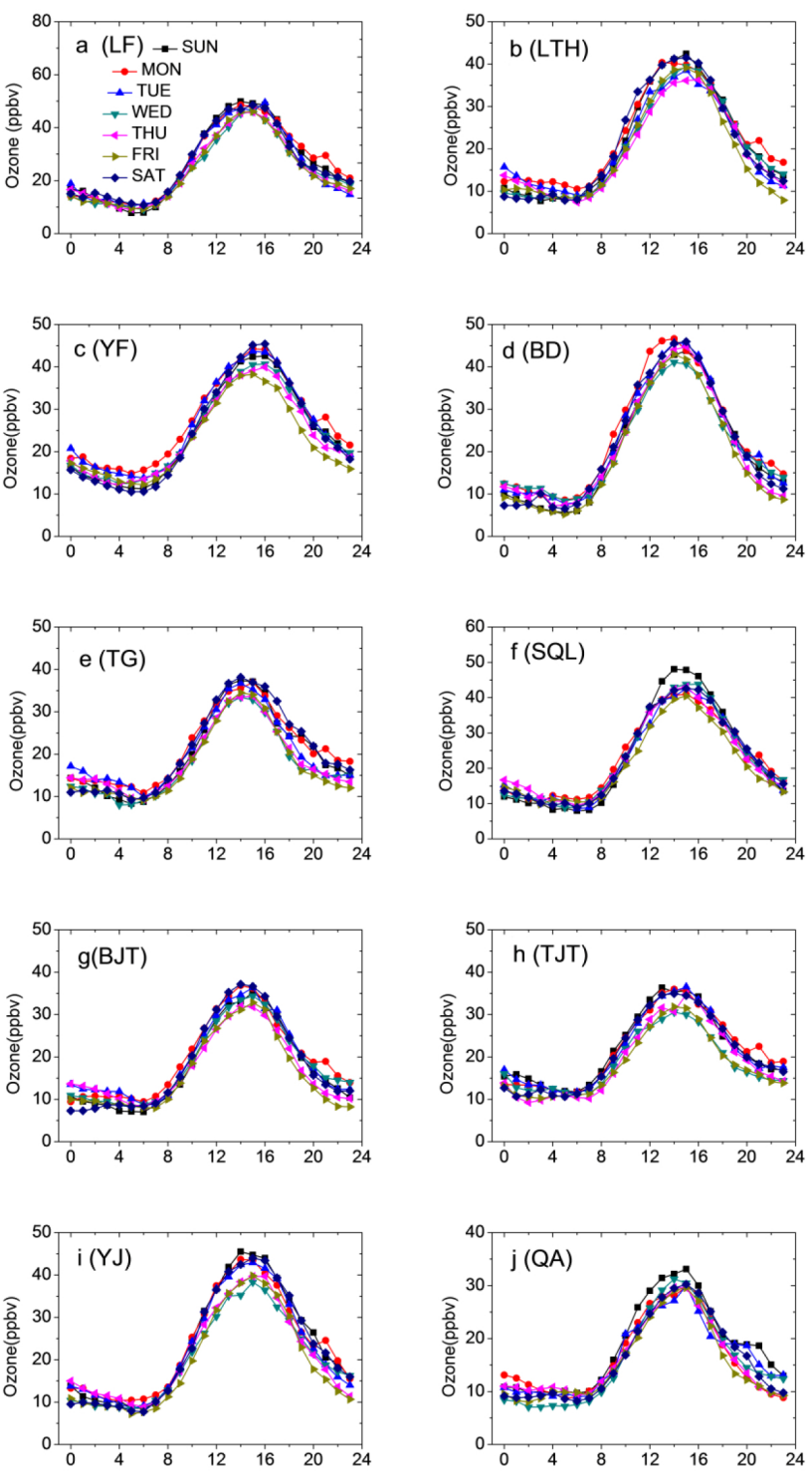

Fig. 5. Diurnal variations of surface ozone concentrations at these observation sites (all figures have the same legend as Fig. 4a).

VOCs $/ \mathrm{NO}_{\mathrm{x}}$ ratios and more ozone production efficiently on Monday. Moreover, we also find an interesting phenomenon in which ozone increases somewhat from 20:00 to 22:00, particularly on Monday (at QA on Sunday). A slight decrease in vehicle activity during this heavy emission period may be responsible for the episode, according to a report by Wei et al. (2004). 
Table 3. The difference (percentage $\%$ ) of $\mathrm{O}_{\mathrm{x}}$ weekend effect minus $\mathrm{O}_{3}$ weekend effect over the study sites.

\begin{tabular}{llllllllll}
\hline LF & LTH & YF & BD & TG & SQL & BJT & TJT & YJ & QA \\
\hline-0.5 & -9.1 & -7.7 & -9.9 & -9.1 & -5.9 & 0.3 & 1.4 & -3.7 & -2.2 \\
\hline
\end{tabular}
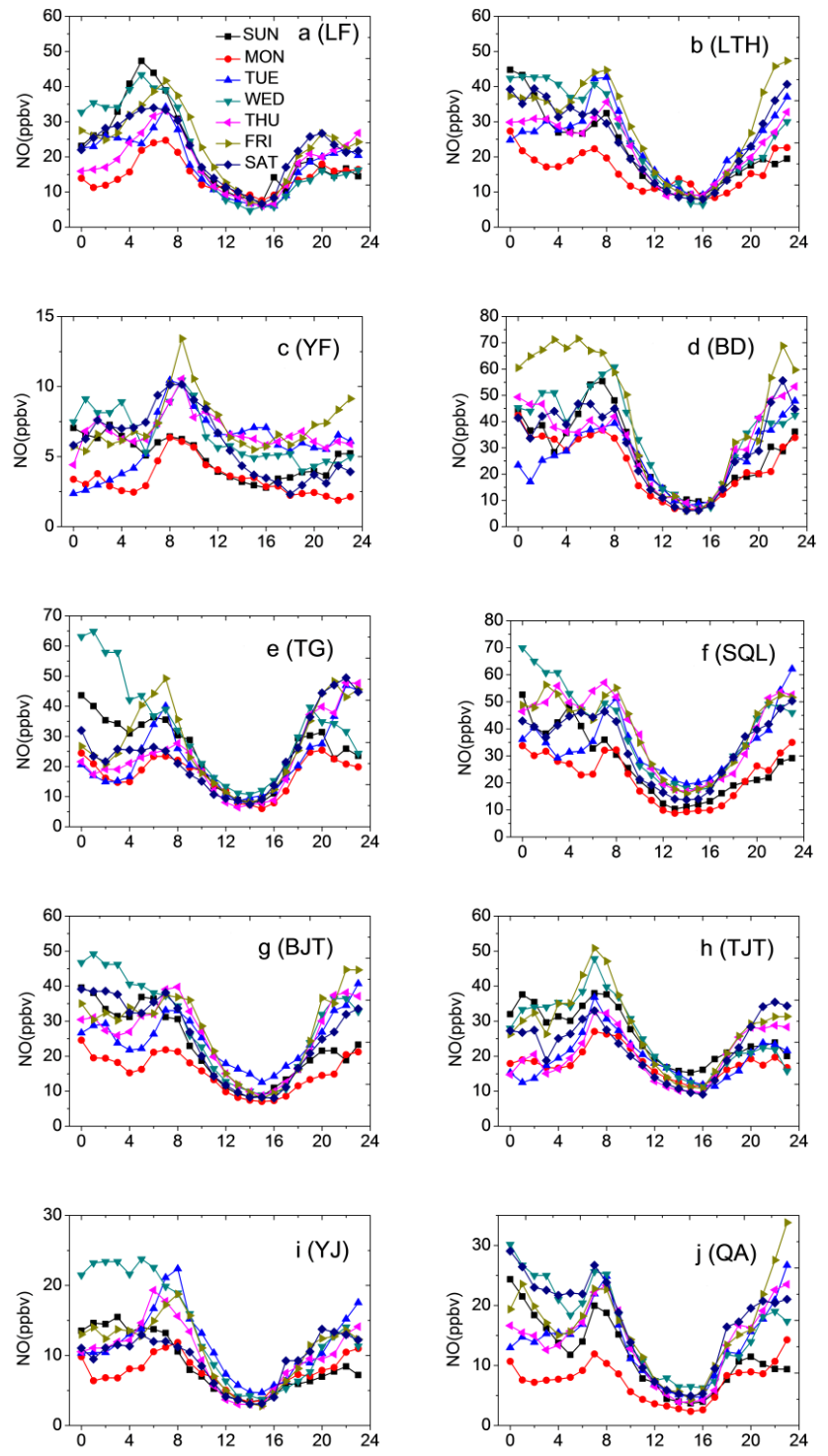

Fig. 6. Diurnal variation of NO concentrations at these sites (all figures have the same legend as Fig. 5a).

\subsection{Causes of the surface ozone weekend effect in the BTH area}

\subsubsection{Decrease in $\mathrm{NO}_{\mathrm{x}}$ and $\mathrm{CO}$ on the weekend}

The BTH area has a high level of $\mathrm{NO}_{\mathrm{x}}$ pollution, as documented in Table 2, regardless of the day of the week. With vehicle sales increasing $32 \%$, to 18.1 million, in 2010 com-
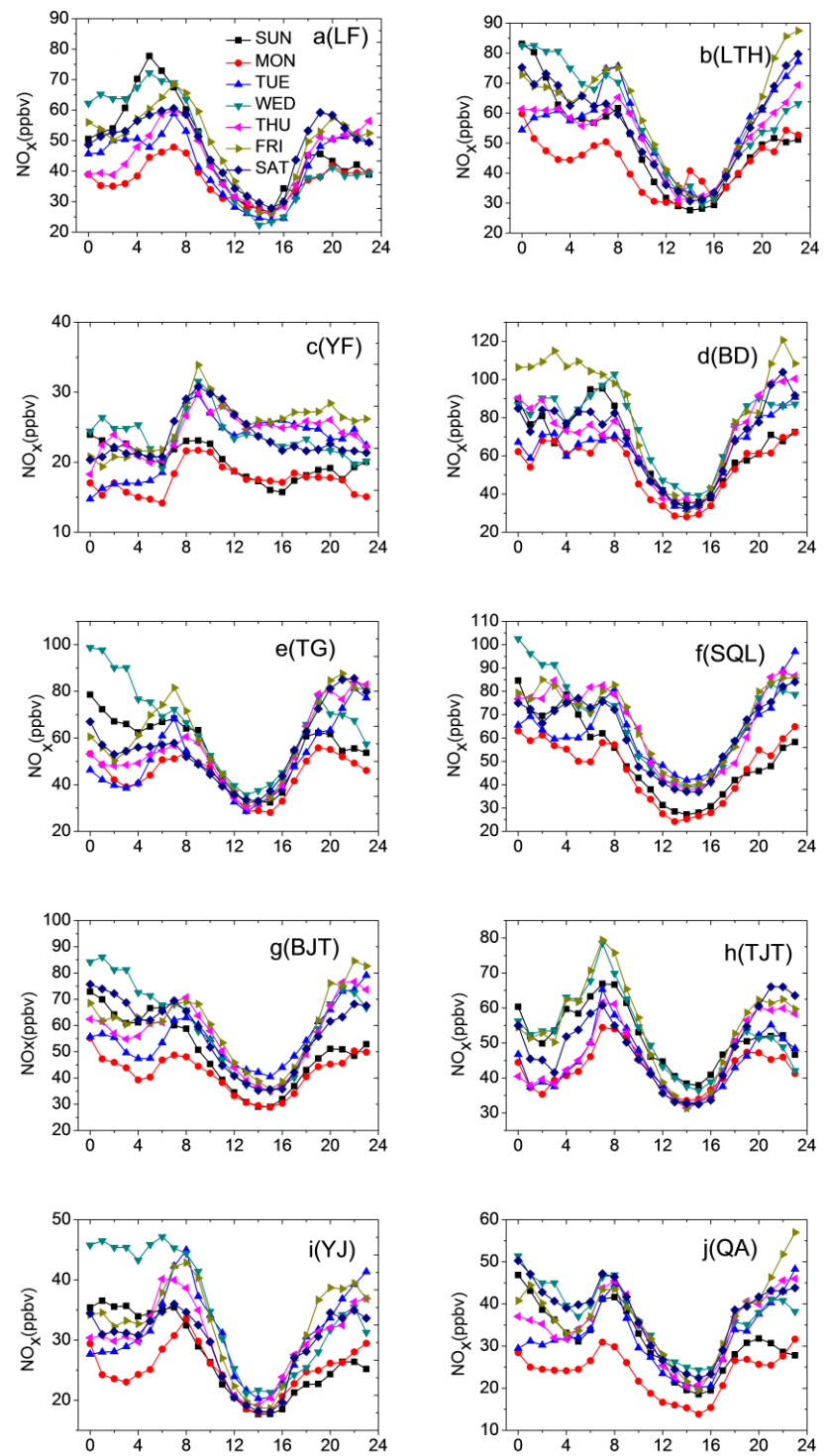

Fig. 7. Diurnal variation of $\mathrm{NO}_{\mathrm{x}}$ concentrations measured at these sites (all figures have the same legend as Fig. 6a).

pared to 2009 (CATARC and CAAM, 2011), on-road vehicle emission is the main source of $\mathrm{NO}_{\mathrm{x}}$ in China (Baker et al., 2008; Wu et al., 2012). The maximum $\mathrm{NO}_{\mathrm{x}}$ levels occur at $\mathrm{BD}, \mathrm{TG}$ and SQL, with average concentrations of $70.2 \mathrm{ppb}$, $61.4 \mathrm{ppb}$ and $62.8 \mathrm{ppb}$ on weekdays and $65.8 \mathrm{ppb}, 54.6 \mathrm{ppb}$ and $53.9 \mathrm{ppb}$ on weekends, respectively. Contrasting with the high $\mathrm{NO}_{\mathrm{x}}$ pollution in surrounding areas, Beijing appears to have progressed in controlling $\mathrm{NO}_{\mathrm{x}}$ emissions after the air 


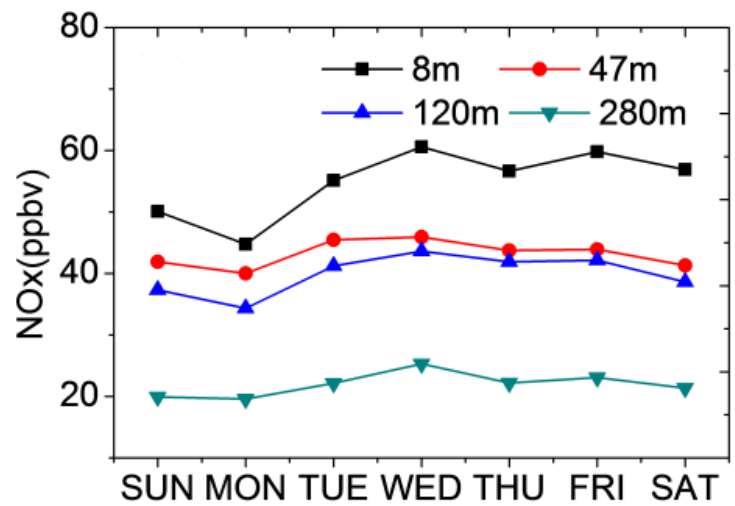

Fig. 8. Weekly variation in $\mathrm{NO}_{\mathrm{x}}$ concentration on $8 \mathrm{~m}, 47 \mathrm{~m}, 120 \mathrm{~m}$ and $280 \mathrm{~m}$ observation platforms of the Beijing meteorological tower.

quality improvements that were made for the 29th Olympic Games (Wang et al., 2010). NO also exhibits high levels in this area, except at YF, YJ and QA. Fig. 6a-j illustrate the diurnal variation in the $\mathrm{NO}$ concentration at 10 sites. A typical diurnal cycle in $\mathrm{NO}_{\mathrm{x}}$, which is dependent on rush hours and photochemical reactions, was also observed, as displayed in Fig. $7 \mathrm{a}-\mathrm{j}$. The maximum values occur during the morning rush hours, at approximately 08:00 LT (Fig. 7), followed by a decrease in the late morning due to lower emissions and the rapid growth of the planetary boundary layer (PBL) (Seinfeld and Pandis, 1998). A secondary maximum occurs due to the evening rush hours and continues. There is no significant decrease in $\mathrm{NO}$ and $\mathrm{NO}_{\mathrm{x}}$ at night due to the accumulation of pollutants, except at the YF site (Figs. 6c and 7c), which is located on a campus where direct vehicle pollution has limited effect.

The weekly cycle of $\mathrm{NO}_{2}$ was investigated by Beirle et al. (2003) using GOME measurements, and they reported a difference between weekdays and weekends that depended on the anthropogenic sources of emissions in Asia. The daily behaviour of $\mathrm{NO}$ and $\mathrm{NO}_{\mathrm{x}}$ also had pronounced differences, as depicted in Figs. 6 and 7. Monday, Sunday and Saturday had lower levels of $\mathrm{NO}$ and $\mathrm{NO}_{\mathrm{x}}$ than the other days of the week. In particular, lower concentrations of both $\mathrm{NO}$ and $\mathrm{NO}_{\mathrm{x}}$ were observed on later night of Sunday and early morning of Monday, and this is mainly due to decreased human activity. It is widely accepted that the OWE in urban areas is partly attributed to a decrease in titration $\left(\mathrm{NO}+\mathrm{O}_{3} \rightarrow \mathrm{NO}_{2}+\mathrm{O}_{2}\right.$ ) (Fishman and Crutzen, 1978; Altshuler et al., 1995; Fujita et al., 2003; Murphy et al., 2007; Tang et al., 2009), which can lead to an accumulation of ozone late Sunday night and early Monday morning. The NO titration hypothesis for the BTH area can be validated using daily ozone profiles, as illustrated in Fig. 5. Ozone displayed high concentrations during daytime and low concentration during nighttime, which suggest a strong photochemical reaction on this region (Wang et al., 2006). The ozone con- centrations were higher during weekend nighttime and lower during weekday nighttime due to the different NO concentration.

The vertical weekly distributions of $\mathrm{NO}_{\mathrm{x}}$ concentrations at $8 \mathrm{~m}, 47 \mathrm{~m}, 120 \mathrm{~m}$ and $280 \mathrm{~m}$ are also displayed in Fig. 8 . $\mathrm{NO}_{\mathrm{x}}$ had high concentration later in the week but a low concentration early in the week at each of the four heights. The minimum concentrations all occurred on Monday due to the reduced human emissions and lower accumulation on weekends. The $\mathrm{NO}_{\mathrm{x}}$ displayed significant weekend effect on low platform, consistent with OWE at low platform. However, this weekend effect is not significant on high platforms, as depicted in Figs. 4 and 8. Both an observational study by Chen et al. (2013) and numerical simulation study by Tang et al. (2010) showed that the peak ozone concentration occurred at nearly $1 \mathrm{~km}$ over BTH area, which suggested that surface ozone mainly came from transition of upper atmosphere. The $\mathrm{NO}_{\mathrm{x}}$ mainly came from surface emissions, so weekly variation of ozone on low platform was influenced more than high platform by $\mathrm{NO}_{\mathrm{x}}$.

There should be a difference between weekday and weekend VOCs, and the change of $\mathrm{VOC} / \mathrm{NO}_{\mathrm{x}}$ mixing ratios should also change according to the variation in their sources in this fast developing area, as in other regions of the world (Atkinson-Palombo et al., 2006; Sadanaga et al., 2008; Shao et al., 2009; Pudasainee et al., 2010). However, direct VOC measurements were not used in our analysis. These types of measurements are relatively sparse for the BTH area and have a low temporal resolution (i.e. one sample a week). Here, we use CO as a proxy for VOCs because of their similar origins (Baker et al., 2008), similar to the method that was used by Stephens et al. (2008) for studying the OWE in Mexico City. VOCs are usually several times more reactive than $\mathrm{CO}$; therefore, it is debatable whether variations in $\mathrm{CO}$ can be used as a proxy for variations in VOC reactivity.

Table 4 lists the weekday and weekend differences in $\mathrm{CO}$ concentrations at the BJT and TJT sites, but $\mathrm{CO}$ data for the other sites are not available. Both $\mathrm{CO}$ concentrations at the two sites decrease over the weekend, with a $4.4 \%$ decrease at BJT and a $3.2 \%$ decrease at TJT. Detailed daily behaviours are illustrated in Fig. 9. The maximum concentration occurred on Wednesday, and the minimum concentration occurred on Monday. Thus, the decrease in VOC concentrations is less than the decrease in $\mathrm{NO}_{\mathrm{x}}$ (Table 2) on the weekend. Moreover, studies (Wang et al., 2006; Tang et al., 2012) have reported that the BTH area may be under a VOClimited regime. Consequently, an increased $\mathrm{VOC} / \mathrm{NO}_{\mathrm{x}}$ ratio on weekends may enhance the ozone production efficiency and lead to higher ozone concentrations.

\subsubsection{Decrease in particles and increase in UV radiation on the weekend}

$\mathrm{PM}_{10}$ and $\mathrm{PM}_{2.5}$ concentrations from the monitoring sites have also been reported for weekdays and weekends to 
Table 4. Weekday and weekend differences in CO concentrations (24 h) and UV radiation (daytime) at the BJT and TJT sites.

\begin{tabular}{rrr|rr|rr|rr}
\hline & \multicolumn{2}{c|}{ Weekday } & \multicolumn{2}{|c|}{ Weekend } & \multicolumn{2}{|c|}{$W$} & \multicolumn{2}{c}{ Percentage } \\
& $(\mathrm{ppbv})$ & $\left(\mathrm{W} \mathrm{m}^{-2}\right)$ & $(\mathrm{ppbv})$ & $\left(\mathrm{W} \mathrm{m}^{-2}\right)$ & $(\mathrm{ppbv})$ & $\left(\mathrm{W} \mathrm{m}^{-2}\right)$ & $(\%)$ \\
\hline BJT & 1656 & 12.3 & 1582 & 12.7 & 74 & 0.4 & 4.4 & 3.3 \\
TJT & 1337 & - & 1294 & - & 43 & - & 3.2 & - \\
\hline
\end{tabular}

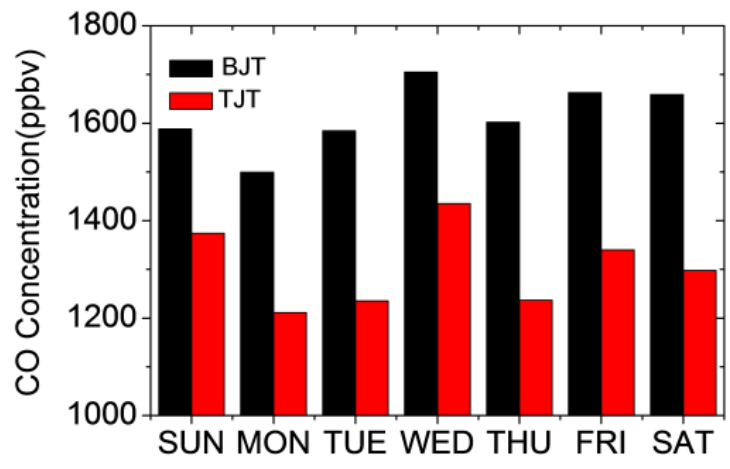

Fig. 9. Weekly variation of CO concentrations at the BJT site and the TJT site.

validate a weekly cycle, along with UV radiation. Our $\mathrm{PM}_{10}$ data were collected by TEOM at LF, YF, BD, TG, BJT, YJ and QA, while $\mathrm{PM}_{2.5}$ data were collected from LTH, SQL, BJT and TJT.

It is well known that TEOM instruments measure lower particle mass values than the collocated filter-based samplers (Cyrys et al., 2001; Xin et al., 2012). The particulate material in the inlet was heated to $50^{\circ}$ to minimize any interference due to the evaporation and condensation of water vapour onto the filter and to obtain a stable and reproducible measurement. However, some semi-volatile aerosol and particle-bound water may leak out due to the heating. In particular, Charron et al. (2004) reported that the difference between TEOM and gravimetric measurements varies according to temperature and relative humidity. The measured TEOM aerosol concentration maybe misleads our understanding of aerosol pollution to some extent. However, in this case, we focus on the concentration anomaly between weekdays and weekends, which limits the error due to temperature and relative humidity.

Table 5 lists the aerosol concentrations and percentage differences at the observation sites on weekdays and weekends. The $\mathrm{PM}_{10}$ pollution is serious, with a range of $186.7 \mu \mathrm{g} \mathrm{m}^{-3}$ at the BD site to $105.1 \mu \mathrm{g} \mathrm{m}^{-3}$ at the YJ site on weekdays and $182.2 \mu \mathrm{g} \mathrm{m}^{-3}$ to $98.4 \mu \mathrm{g} \mathrm{m}^{-3}$ on weekends, respectively. The $\mathrm{PM}_{2.5}$ also has a high concentration, from $89.1 \mu \mathrm{g} \mathrm{m}^{-3}$ at the SQL site to $61.4 \mu \mathrm{g} \mathrm{m}^{-3}$ at the LTH site on weekdays and $82.2 \mu \mathrm{g} \mathrm{m}^{-3}$ to $58.7 \mu \mathrm{g} \mathrm{m}^{-3}$ on weekends, respectively. In addition, the statistics for the percentage differences, listed in Table 5, indicate that the maximum $\mathrm{PM}_{2.5}$ concentration
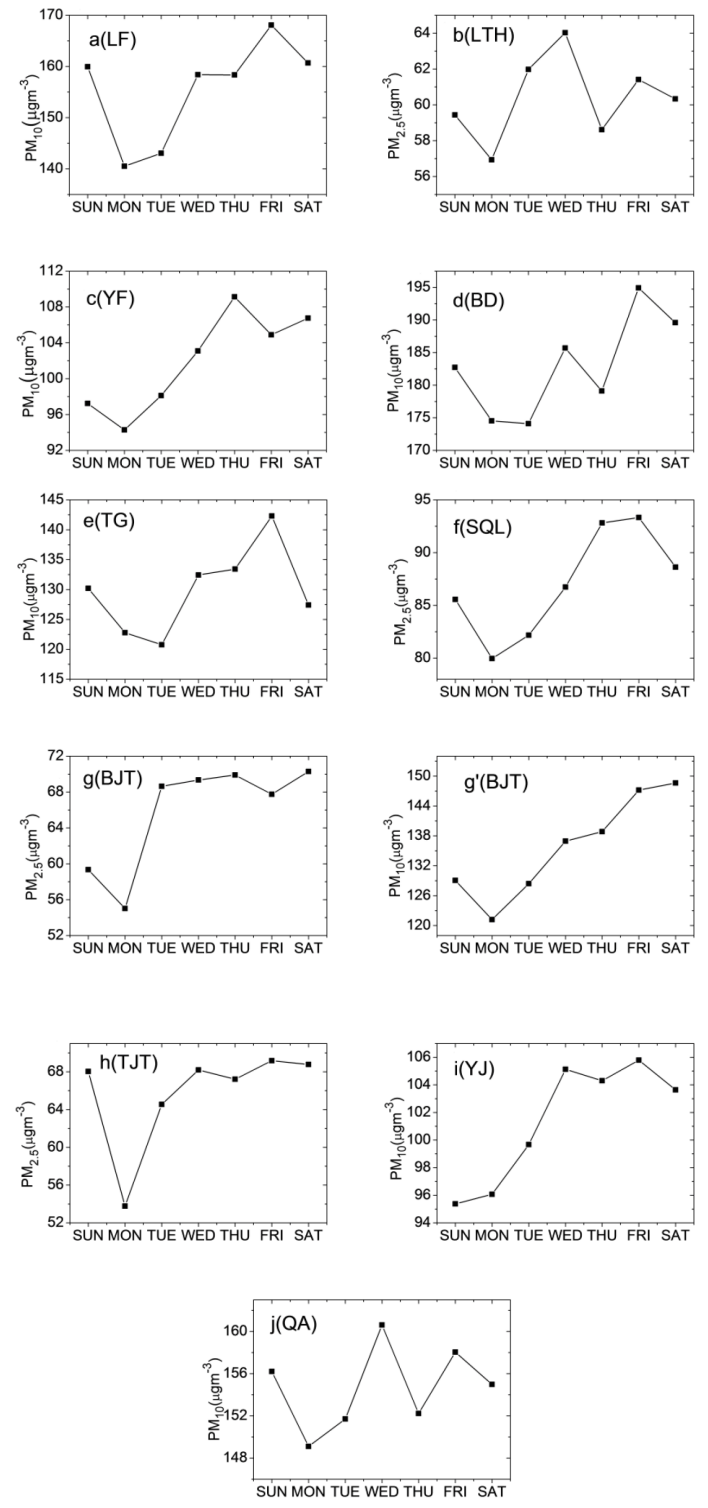

Fig. 10. Weekly variations in aerosol concentrations at these sites. In particular, both $\mathrm{PM}_{10}$ and $\mathrm{PM}_{2.5}$ concentrations were measured at the BJT site.

decrease of $10.7 \%$ occurs at BJT, on weekends compared to weekdays. The emissions of $\mathrm{PM}_{2.5}$ are more relevant to human activity than $\mathrm{PM}_{10}$ (Xin et al., 2012), and $\mathrm{PM}_{2.5}$ decreased more over the weekend than $\mathrm{PM}_{10}$, as indicated 
Table 5. Weekday and weekend differences of aerosol concentrations using $24 \mathrm{~h}$ data at these sites.

\begin{tabular}{|c|c|c|c|c|}
\hline & $\begin{array}{l}\text { Weekday } \\
\left(\mu \mathrm{g} \mathrm{m}^{-3}\right)\end{array}$ & $\begin{array}{l}\text { Weekend } \\
\left(\mu \mathrm{g} \mathrm{m}^{-3}\right)\end{array}$ & $\begin{array}{r}W \\
\left(\mu \mathrm{g} \mathrm{m}^{-3}\right)\end{array}$ & $\begin{array}{r}\text { Percentage } \\
(\%)\end{array}$ \\
\hline $\mathrm{LF}\left(\mathrm{PM}_{10}\right)$ & 161.6 & 153.7 & 7.9 & 4.9 \\
\hline LTH $\left(\mathrm{PM}_{2.5}\right)$ & 61.4 & 58.7 & 2.7 & 4.4 \\
\hline $\mathrm{YF}\left(\mathrm{PM}_{10}\right)$ & 105.7 & 99.6 & 6.1 & 5.8 \\
\hline $\mathrm{BD}\left(\mathrm{PM}_{10}\right)$ & 186.7 & 182.2 & 4.5 & 2.4 \\
\hline $\mathrm{TG}\left(\mathrm{PM}_{10}\right)$ & 136.5 & 130.1 & 6.4 & 4.7 \\
\hline $\operatorname{SQL}\left(\mathrm{PM}_{2.5}\right)$ & 89.1 & 82.2 & 6.9 & 7.7 \\
\hline $\mathrm{BJT}\left(\mathrm{PM}_{2.5}\right)$ & 68.9 & 61.5 & 7.4 & 10.7 \\
\hline $\mathrm{BJT}\left(\mathrm{PM}_{10}\right)$ & 140.7 & 132.9 & 7.8 & 5.5 \\
\hline $\mathrm{TJT}\left(\mathrm{PM}_{2.5}\right)$ & 68.2 & 63.5 & 4.7 & 6.9 \\
\hline $\mathrm{YJ}\left(\mathrm{PM}_{10}\right)$ & 105.1 & 98.4 & 6.7 & 6.4 \\
\hline $\mathrm{QA}\left(\mathrm{PM}_{10}\right)$ & 158.6 & 150.9 & 7.7 & 4.9 \\
\hline
\end{tabular}

in Table 5. Figure 10a-j illustrate the daily behaviours of aerosol concentrations at each site. The maximum concentrations usually occur on Friday (Fig. 10a, c, d, e, f, g, h, i) or Wednesday (Fig. 10b, g, j), mainly due to the accumulation of pollutants from the beginning of the week. The minimum concentration is observed on weekends, mostly due to a decrease in emissions from vehicles and factories (Gong et al., 2007). The higher particle concentration on weekdays in China was also reported by Gong et al. (2007) using a daily API (air pollution index).

Aerosols can effect radiation through both absorption and scattering. The absorption of UV radiation by aerosols leads to a reduced availability of photons; however, scattering aerosols may decrease the photon flux received near the surface (Murphy et al., 2007). Some analyses have been conducted and suggested a difference in the UV radiation level on weekends and weekdays due to a difference in the aerosol concentration (Murphy et al., 2007; Tang et al., 2009), but they do not show a direct reduction in UV radiation needed for photochemical reactions. To further investigate the weekly cycle of aerosol concentrations and its effect on the energy of photochemical reactions, we analysed the weekly variation in UV radiation at the BJT site because data at the other sites were unavailable. Figure 11 illustrates the weekly variation in UV radiation $(290-400 \mathrm{~nm})$ at the BJT site. The UV radiation is calculated using only daytime and valid data, while weekly variations of aerosol concentration were calculated based on $24 \mathrm{~h}$ averaged value. The minimum value was observed on Wednesday, and the maximum value was observed on Sunday, which is generally consistent with the variation in aerosol concentrations at the BJT site. The statistics from Table 4 indicate that UV radiation was $12.3 \mathrm{Wm}^{-2}$ on weekdays and $12.7 \mathrm{Wm}^{-2}$ on weekends, based on surface observation, with a difference of $3.3 \%$.

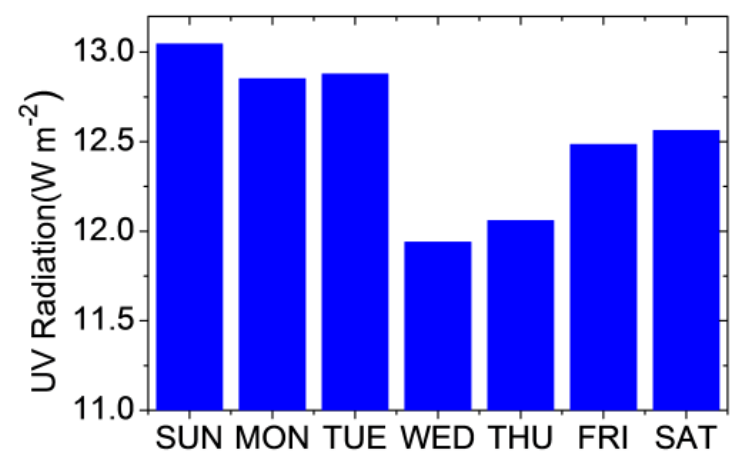

Fig. 11. Weekly variation in UV $(290-400 \mathrm{~nm})$ radiation at the BJT site.

\section{Summary and conclusion}

The ozone weekend effect (OWE) was investigated at 10 surface sites and the meteorological tower over the BeijingTianjin-Hebei metropolitan area of China from July 2009 to August 2011. The analysis indicates that all of the sites have higher ozone concentrations on weekends than on weekdays. The urban core sites, such as TJT, SQL, BD and BJT, had slight OWEs, according to ozone anomalies, while other urban sites had larger OWEs. The variations of $\mathrm{O}_{\mathrm{x}}$ did not show consistent weekly variations with $\mathrm{O}_{3}$. The analysis of $\mathrm{NO}$ also revealed a weekly cycle, with the maximum level occurring on weekdays and the minimum level occurring on weekends, which implied that a decrease in NO titration on the weekends, especially later Sunday night and early Monday morning, may be responsible for the higher concentration of ozone then. The vertical variations of ozone and $\mathrm{NO}_{\mathrm{x}}$ on four platforms of $325 \mathrm{~m}$ Beijing meteorological tower also displayed significant weekly cycles, consistent with surface results. Moreover, a smaller decrease in VOCs (using $\mathrm{CO}$ as a proxy) and a much lower concentration of $\mathrm{NO}_{\mathrm{x}}$ on weekends may lead to increasing $\mathrm{VOC} / \mathrm{NO}_{\mathrm{x}}$ ratios, which can enhance the ozone production efficiency in VOC regime areas. This process may be a cause of the OWE in BTH.

Additionally, a clear weekly cycle in aerosol concentrations was observed at selected sites, with maximum values occurring on weekdays and minimum values occurring on weekends. UV radiation from surface measurements at the BJT site indicated a significant weekly cycle, consistent with the aerosol concentration. This fact suggested that a higher concentration of aerosol on weekdays may reduce the UV radiation flux by absorption or scattering than that on weekends, and lead to a decrease in photochemical reactions of ozone formation. These results provide additional scientific basis for determining the characteristics of this photochemical pollution, and we hope they will benefit air pollution control efforts in the region. 
Acknowledgements. We would like to thank all of the staff at the Atmospheric Environment Monitoring Network for instrument maintenance, particularly for data software maintenance by associate professor Sun Yang (patent 201110314550.7). We acknowledge $\mathrm{S}$. Madronich and the other two anonymous reviewers for their constructive comments. This work was supported by the National Natural Science Foundation of China (41230642) and the CAS Strategic Priority Research Program grant no. XDA05100100 and no. XDB05020402.

Edited by: A. B. Guenther

\section{References}

Altshuler, S. L., Arcado, T. D., and Lawson, D. R.: Weekday versus weekend ambient ozone concentrations: Discussion and hypotheses with focus on Northern California, JAPCA J. Air Waste Ma., 45, 967-972, 1995.

Atkinson-Palombo, C. M., Miller, J. A., and Balling, R. C.: Quantifying the ozone "weekend effect" at various locations in Phoenix, Arizona, Atmos. Environ., 40, 7644-7658, 2006.

Baker, A. K., Beyersdorf, A. J., Doezema, L. A., Katzenstein, A., Meinardi, S., Simpson, I. J., Blake, D. R., and Rowland, F. S.: Measurements of nonmethane hydrocarbons in 28 United States cities, Atmos. Environ., 42, 170-182, 2008.

Beirle, S., Platt, U., Wenig, M., and Wagner, T.: Weekly cycle of $\mathrm{NO}_{2}$ by GOME measurements: a signature of anthropogenic sources, Atmos. Chem. Phys., 3, 2225-2232, doi:10.5194/acp3-2225-2003, 2003.

California Air Resources Board: The Ozone Weekend Effect in California, CARB Planning and Technical Support Division, Sacramento, 2003.

CATARC (China Automotive Technology and Research Center) and CAAM (Chinese Association of Automotive Manufactures): China Automotive Industry Yearbooks, 2011 (in Chinese).

Chan, K. C. and Yao, X.: Air pollution in mega cities in China, Atmos. Environ., 42, 7053-7063, 2008.

Charron, A., Harrison, R. M., Moorcroft, S., and Booker, J.: Quantitative interpretation of divergence between $\mathrm{PM}_{10}$ and $\mathrm{PM}_{2.5}$ mass measurement by TEOM and gravimetric (Partisol) instruments, Atmos. Environ., 38, 415-423, 2004.

Chen, P., Quan, J., Zhang, Q., Tie, X., Gao, Y., and Huang, M.: Measurements of vertical and horizontal distributions of ozone over Beijing from 2007-2010, Atmos. Environ., 74, 37-44, 2013.

China State Council, Comprehensive Framework on Energy Saving and Emission Reduction for the 12th Five Year Plan, http: //www.gov.cn/zwgk/2011-09/07/content_1941731.htm (last access: 5 March 2014), 2011 (in Chinese).

Chou, C. C. K., Tsai, C. Y., Shiu, C. J., Liu, S. C., and Zhu, T.: Measurement of $\mathrm{NO}_{\mathrm{y}}$ during Campaign of Air Quality Research in Beijing 2006(CAREBeijing-2006): Implications for the ozone production efficiency of $\mathrm{NO}_{\mathrm{x}}$, J. Geophy. Res., 114, D00G01, doi:10.1029/2008JD010446, 2009.

Cleveland, W. S. and McRae, J. E.: Weekend-Weekend Ozone Concentrations in the Northeast United States, Environ. Sci. Technol., 12, 558-563, 1978.

Cleveland, W. S., Graedel, T. E., Kleiner, B., and Warner, J. L.: Sunday and workday variations in photochemical air pollutants in New Jersey and New York, Science, 186, 1037-1038, 1974.
Cyrys, J., Dietrch, G., Kreyling, W., Tuch, T., and Heinrich, J.: $\mathrm{PM}_{2.5}$ measurements in ambient aerosol: comparison between Harvard impactor (HI) and the tapered element oscillation microbalance (TEOM) system, Sci. Total. Environ., 278, 191-197, 2001.

Fishman, J. and Crutzen, P. J.: The origin of ozone in troposphere, Nature, 274, 855-858, 1978.

Forster, P. M. F. and Solomon, S.: Observations of a "weekend effect" in diurnal temperature range, PNAS Proc. Natl. Acad. Sci. USA, 100, 11225-11230, 2003.

Fujita, E. M., Stockwell, W. R., Campbell, D. E., Keislar, R. E., and Lawson, D. R.: Evolution of the magnitude and spatial extent of the weekend ozone effect in California's South Coast Air Basin, 1981-2000, JAPCA J. Air Waste Ma., 53, 802-815, 2003.

Gong, D. Y., Guo, D., and Ho, C. H.: Weekend effect in diurnal temperature range in China: Opposite signals between winter and summer, J. Geophys. Res., 111, D18113, doi:10.1029/2006JD007068, 2006.

Gong, D. Y., Ho, C. H., Chen, D., Qian, Y., Choi, Y. S., and Kim, J.: Weekly cycle of aerosol-meteorology interaction over China, J. Geophys. Res., 112, D22202, doi:10.1029/2007JD008888, 2007.

Ho, C. H., Choi, Y. S., and Hur, S. K.: Long-term changes in summer weekend effect over northeastern China and the connection with regional warming, Geophys. Res. Lett., 36, L15706, doi:10.1029/2009GL039509, 2009.

Hu, B., Wang, Y. S., and Liu, G. R.: Influences of the Clearness Index on UV Solar Radiation for Two Locations in the Tibetan Plateau-Lhasa and Haibei, Adv. Atmos. Sci., 25, 885-896, 2008.

Ji, D. S., Wang, Y. S., Wang, L. L., Chen, L. F., Hu, B., Tang, G. Q., Xin, J. Y., Song, T., Wen, T. X., Sun, Y., Pan, Y. P., and Liu, Z, R.: Analysis of heavy pollution episodes in selected cities of Northern China, Atmos. Environ., 50, 338-348, 2012.

Karl, T. R.: Day of week variations of photo-chemical pollutants in St. Louis area, Atmos. Environ., 8, 1657-1667, 1978.

Koo, B., Jung, J., Pollack, A. K., Lindhjem, C., Jimenz, M., and Yarwood, G.: Impact of meteorology and anthropogenic emissions on the local and regional ozone weekend effect in Midwestern US, Atmos. Environ., 57, 13-21, 2012.

Lebron, F.: A comparison of weekend-weekday ozone and hydrocarbon concentration in the Baltimore-Washington metropolitan area, Atmos. Environ., 9, 861-863, 1975.

Levitt, S. B. and D. P., Chock.: Weekday-weekend pollutant studies of Los Angeles Basin, J. Air Pollut. Control Assoc., 11, 1091$1092,1976$.

Lin, W., Xu, X., Ge, B., and Liu, X.: Gaseous pollutants in Beijing urban area during the heating period 2007-2008: variability, sources, meteorological, and chemical impacts, Atmos. Chem. Phys., 11, 8157-8170, doi:10.5194/acp-11-8157-2011, 2011.

MEP (Ministry of Environmental Protection, P. R. China): Air quality bulletin for key environmental protection cities in the 1st half of 2011, http://www.mep.gov.cn/gkml/hbb/bgg/201107/ W020110730434018324100.pdf (last access: 5 March 2014), 2011 (in Chinese).

Murphy, J. G., Day, D. A., Cleary, P. A., Wooldridge, P. J., Millet, D. B., Goldstein, A. H., and Cohen, R. C.: The weekend effect within and downwind of Sacramento - Part 1: Observations of ozone, nitrogen oxides, and VOC reactivity, Atmos. Chem. Phys., 7, 5327-5339, doi:10.5194/acp-7-5327-2007, 2007. 
NRC (National Research Council): Rethinking the Ozone Problem in urban and Regional Air Pollution, National Academic Press, DC, USA, 1991.

Pont, V. and Fontan, J.: Comparison between weekend and weekday ozone concentration in large cities in France, Atmos. Environ., 35, 1527-1535, 2001.

Pudasainee, D., Sapkota, B., Bhatnagar, A., Kim, S. H., and Seo, Y. C.: Influence of weekdays, weekends and bandhas on surface ozone in Kathmandu valley, Atmos. Res., 95, 150-156, 2010.

Randall, S. C. and Robert, C. B.: Weekly cycles of air pollutants, precipitation and tropical cyclones in the coastal NW Atlantic region, Nature, 394, 561-563, 1998.

Sadanaga, Y., Shibata, S., Hamana, H., Takenaka, N., and Bandow, H.: Weekday/weekend difference of ozone and its precursors in urban areas of Japan, focusing on nitrogen oxides and hydrocarbons, Atmos. Environ., 42, 4708-4723, 2008.

Seinfeld, J. H. and Pandis, S. N.: Atmospheric Chemistry and physics, From Air Pollution to Climate Changes, Wiley, New York, USA, 1998.

Shao, M., Lu, S., Liu, Y., Xie, X., Chang, C., Huang, S., and Chen, Z.: Volatile organic compounds measured in summer in Beijing and their role in ground-level ozone formation, J. Geophys. Res., 114, D00G06, doi:10.1029/2008JD010863, 2009.

Stephens, S., Madronich, S., Wu, F., Olson, J. B., Ramos, R., Retama, A., and Muñoz, R.: Weekly patterns of México City's surface concentrations of $\mathrm{CO}, \mathrm{NO}_{\mathrm{x}}, \mathrm{PM}_{10}$ and $\mathrm{O}_{3}$ during 19862007, Atmos. Chem. Phys., 8, 5313-5325, doi:10.5194/acp-85313-2008, 2008.

Tang, G.: Modeling of ozone spatial-temporal distribution in the vicinity of Beijing during Olympics, Ph.D thesis, Chinese Academy of Sciences, 2010.

Tang, G., Li, X., Wang, Y., Xin, J., and Ren, X.: Surface ozone trend details and interpretations in Beijing, 2001-2006, Atmos. Chem. Phys., 9, 8813-8823, doi:10.5194/acp-9-8813-2009, 2009.

Tang, G., Wang, Y., Li, X., Ji, D., Hsu, S., and Gao, X.: Spatialtemporal variations in surface ozone in Northern China as observed during 2009-2010 and possible implications for future air quality control strategies, Atmos. Chem. Phys., 12, 2757-2776, doi:10.5194/acp-12-2757-2012, 2012.

Tang, W. Y., Zhao, C. S., Geng, F. H., Peng, L., Zhou, G. Q., Xu, J. M., and Tie, X. X.: Study of ozone "weekend effect" in Shanghai, Sci. China Ser. D, 51, 1354-1360, 2008.

Tasi, Y. I.: Atmospheric visibility trends in an urban area in Taiwan 1961-2003, Atmos. Environ., 39, 5555-5567, 2005.

US EPA, Environmental Protection Agency 40 CFR Parts 53 and 58 [EPA-HQ-OAR-2004-0018: FRL-] RIN 2060-AJ25, http:// www.epa.gov/ttn/amtic/files/ambient/pm25/092706sign.pdf (last access: 5 March 2014), 2004.
Wang, T., Ding, A., Gao, J., and Wu, W. S.: Strong ozone production in urban plumes from Beijing, China, Geophys. Res. Lett., 33, L21806, doi:21810.21029/22006GL027689, 2006.

Wang, T., Nie, W., Gao, J., Xue, L. K., Gao, X. M., Wang, X. F., Qiu, J., Poon, C. N., Meinardi, S., Blake, D., Wang, S. L., Ding, A. J., Chai, F. H., Zhang, Q. Z., and Wang, W. X.: Air quality during the 2008 Beijing Olympics: secondary pollutants and regional impact, Atmos. Chem. Phys., 10, 7603-7615, doi:10.5194/acp10-7603-2010, 2010.

Wang, Y., Zhang, Y., Hao, J., and Luo, M.: Seasonal and spatial variability of surface ozone over China: contributions from background and domestic pollution, Atmos. Chem. Phys., 11, 35113525, doi:10.5194/acp-11-3511-2011, 2011.

Wei, M., Chen, L., Chi, R., Cao, Z., and Yang, F.: Survey and analysis of traffic flow at typical intersection of congested road in Beijng, Journal of China Agricultural University, 9, 91-95, 2004 (in Chinese).

Wu, Y., Zhang, S. J., Li, M. L., Ge, Y. S., Shu, J. W., Zhou, Y., Xu, Y. Y., Hu, J. N., Liu, H., Fu, L. X., He, K. B., and Hao, J. M.: The challenge to $\mathrm{NO}_{\mathrm{x}}$ emission control for heavy-duty diesel vehicles in China, Atmos. Chem. Phys., 12, 9365-9379, doi:10.5194/acp12-9365-2012, 2012.

Xia, X., Eck, T., Holben, B., Phillippe, G., and Chen, H.: Analysis of the weekly c ycle of aerosol depth using AERONET and MODIS data, J. Geophys. Res., 113, D14217, doi:10.1029/2007JD009604, 2008.

Xin, J., Wang, Y., Wang, L., Tang, G., Sun, Y., Pan, Y., and Ji, D.: Reduction of $\mathrm{PM}_{2.5}$ in Beijing-Tianjin-Hebei urban Agglomerations during the 2008 Olympic Games, Adv. Atmos. Sci., 29, 1330-1342, 2012.

Xu, J., Ma, J. Z., Zhang, X. L., Xu, X. B., Xu, X. F., Lin, W. L., Wang, Y., Meng, W., and Ma, Z. Q.: Measurements of ozone and its precursors in Beijing during summertime: impact of urban plumes on ozone pollution in downwind rural areas, Atmos. Chem. Phys., 11, 12241-12252, doi:10.5194/acp11-12241-2011, 2011.

Xu, W. Y., Zhao, C. S., Ran, L., Deng, Z. Z., Liu, P. F., Ma, N., Lin, W. L., Xu, X. B., Yan, P., He, X., Yu, J., Liang, W. D., and Chen, L. L.: Characteristics of pollutants and their correlation to meteorological conditions at a suburban site in the North China Plain, Atmos. Chem. Phys., 11, 4353-4369, doi:10.5194/acp-114353-2011, 2011. 